UDC $579.69+577.112$

\title{
Recombinant Staphylococcal protein A with cysteine residue for preparation of affinity chromatography stationary phase and immunosensor applications
}

\author{
O. B. Gorbatiuk ${ }^{1,2}$, A. O. Bahmachuk ${ }^{1,3}$, L. V. Dubey ${ }^{1}$, M. O. Usenko ${ }^{1,3}$, \\ D. M. Irodov ${ }^{1,2}$, O. V. Okunev ${ }^{1,2}$, O. M. Kostenko ${ }^{1}$, A. E. Rachkov', V.A. Kordium ${ }^{1,2}$ \\ ${ }^{1}$ Institute of Molecular Biology and Genetics, NAS of Ukraine \\ 150, Akademika Zabolotnoho Str., Kyiv, Ukraine, 03680 \\ ${ }^{2}$ State Institute of Genetic and Regenerative Medicine, NAMS of Ukraine \\ 67, Vyshhorodska Str., Kyiv, Ukraine, 04114 \\ ${ }^{3}$ Educational and Scientific Center «Institute of Biology», \\ Taras Shevchenko National University of Kyiv \\ 64/13, Volodymyrska Str., Kyiv, Ukraine, 01601 \\ gorbatuyk@ukr.net
}

\begin{abstract}
Aim. Engineering of recombinant Staphylococcal protein A with cysteine residue (SPA-Cys) for preparation of affinity chromatography stationary phase and formation of bioselective element of immunosensor. Methods. DNA sequences encoding IgG-binding region of SPA, His-tag and cysteine were genetically fused and expressed in E. coli. SPA-Cys was immobilized on maleimide-functionalized silica beads for affinity chromatography stationary phase preparation and on a gold sensor surface as a bioselective element of immunosensor. Results. SPA-Cys was expressed at a high-level in a soluble form. The target protein was purified and showed a high IgG-binding activity. The capacity of the obtained SPA-Cys-based affinity chromatography stationary phase was $10-12 \mathrm{mg}$ of $\mathrm{IgG} / \mathrm{ml}$. The purity of eluted $\mathrm{IgG}$ was more than $95 \%$ in one-step purification procedure. The developed SPA-Cys-based bioselective element of immunosensor selectively interacted with human IgG and did not interact with the control proteins. Conclusions. The recombinant Staphylococcal protein A with cysteine residue was successfully used for the preparation of affinity chromatography stationary phase and formation of the bioselective element of immunosensor.
\end{abstract}

Keyword s: antibodies, recombinant Staphylococcal protein A, protein immobilization, affinity chromatography, immunosensor, surface plasmon resonance.

\section{Introduction}

The investigations of molecular mechanisms of the pathogen-host interaction revealed microbial proteins capable of non-immune binding with host immunoglobulins without the involvement of their antigen-binding sites. Such non-immune binding of immunoglobulins by bacterial cells through immunoglobulin-binding proteins allows the microorganisms to evade the protective factors of the host body [1]. Staphylococcal Protein A (SPA) was identified as the first protein that binds human $\operatorname{IgG}$ in a nonimmune manner (its $\mathrm{Fc}$-fragment) [2]. Now it is one of the most extensively studied immunoglobulinbinding molecules. The SPA molecule structure includes a signaling sequence [3], IgG-binding region consisting of five highly homologous domains, and a $C$-terminal anchoring part, which attaches the protein to the bacterial cell wall $[4,5]$. The SPA molecules are highly resistant to the denaturing factors: they are thermostable, resistant to a wide range of $\mathrm{pH}(1-12)$, and are not destroyed by trypsin cleavage

\footnotetext{
(C) 2015 O. B. Gorbatiuk et al.; Published by the Institute of Molecular Biology and Genetics, NAS of Ukraine on behalf of Biopolymers and Cell. This is an Open Access article distributed under the terms of the Creative Commons Attribution License (http://creativecommons.org/licenses/by/4.0/), which permits unrestricted reuse, distribution, and reproduction in any medium, provided the original work is properly cited
} 
[1]. Due to the high affinity for the Fc-fragment of a wide spectrum of immunoglobulins, SPA can be used in biotechnology and health care, in particular, in test systems for the immune diagnosis and also as the components of affinity chromatography stationary phase for the purification of antibodies or in the treatment of patients who need the autoantibodies, immune complexes, or immunoglobulins to be removed $[1,6]$.

Among immunological test systems, immunosensors offer a high specificity, simple operation, easy sample preparation and high sensitivity [7]. Using the real-time label-free method based on the surface plasmon resonance (SPR) spectrometry for the immunosensor development seems especially promising and attractive, because it can overcome serious drawbacks of the methods based on molecular labels applications (time- and cost consuming preparation of the labeled components, a possible influence of labels on interacting biomolecules, multi-step detection protocols, etc.) [8]. SPR spectrometer registers the changes in the refractive index of a thin layer $(\sim 200 \mathrm{~nm})$ of media adjacent to a sensor surface. The processes of biomacromolecules immobilization and interactions of immobilized components with their molecules-partners change the refractive index of this layer and evoke the SPR response in real time. However, the immobilization of antibodies on the sensor surface usually leads to lowering their antigen-binding activity. A random orientation of immobilized antibody and steric constraints are believed to be the main reasons of it. To prevent this, the intermediate layer could be created, which would include the immunoglobulin-binding proteins, e.g. Staphylococcal protein A. The SPA molecules can be physically adsorbed on the sensor surface, though the genetic engineering introduction of a cysteine residue to the protein C-terminus was shown to increase the immobilization level of SPA, its IgG-binding activity as well as the further antigen-binding activity of the antibody molecules immobilized through SPA [9]. The efficient immobilization of SPA molecules, bearing cysteine residues, on the gold sensor surface is mediated by a strong thiol-gold interaction [10].

The introduction of a cysteine residue to the Cterminus of SPA molecules opens up new opportuni- ties for the creation of IgG-specific stationary phase for the affinity chromatography. The preparation of such stationary phase is usually based on non-specific chemical coupling strategies. The common problems of these methods are the random orientation and low yield of functional immobilized proteins. The recent advances in synthetic chemistry have been realized in the powerful, efficient and facile methods of the site-specific protein immobilization on a polymer matrix. The site-selective methods allow an attachment of uniformly oriented proteins to the bioactive site freely accessible for further applications. The cysteine residue is highly suitable for immobilization as its thiol group readily undergoes the nucleophilic substitution reaction with electrophilic reagents, or Michael addition to $\alpha, \beta$-unsaturated carbonyls (e.g., maleimides) to form stable thioether bonds. The maleimide groups strongly favor the reaction with thiols at physiological conditions $(\mathrm{pH}$ 6.5-7.5) [11, 12]. The spherical polymeric particles of monodisperse size are the most useful matrix for many solid-phase separation and analytical processes. The thiol addition to maleimide is widely used for the preparation of peptide and oligonucleotide conjugates and arrays, biosensors, fluorescent labeling of proteins and other biomolecules, etc. [13-15]. Therefore, we have employed thiol-maleimide chemistry for the SPA-Cys immobilization onto spherical silica beads.

The aim of the present work is the synthesis and purification of recombinant Staphylococcal protein A with cysteine residue that can be used for the preparation of affinity chromatography stationary phase and the immunosensors development.

\section{Materials and Methods}

$\mathrm{NaCl},\left(\mathrm{NH}_{4}\right)_{2} \mathrm{SO}_{4}, \mathrm{KH}_{2} \mathrm{PO}_{4}, \alpha$-lactose, EDTA, SDS, imidazole, TWEEN 20, TWEEN 80, Triton X 100, Bromophenol Blue and bovine serum albumin (BSA) were purchased from «Sigma» (USA), $\mathrm{Na}_{2} \mathrm{HPO}_{4}$ and glycerol - from «Applichem» (Germany), Dithiotreitol (DTT), Coomassie Brilliant Blue R250 and Unstained Protein Molecular Weight Marker SM0431 from «Fermentas» (Lithuania), Guanidine hydrochloride, Urea and Tris- $\mathrm{HCl}$ buffer solution $(\mathrm{pH} 8.0)-$ 
from «Helicon» (Russia), kanamicin and $\mathrm{MgSO}_{4}-$ from «Arterium» (Ukraine), glucose - from «Farmak» (Ukraine). Glucose Oxidase was obtained from Institute of Microbiology of National Academy of Sciences of Belarus. High purity grade spherical silica beads $\left(20-45 \mu \mathrm{m}\right.$, pore size $60-80 \AA, 420-530 \mathrm{~m}^{2} / \mathrm{g}$ surface area) and 3-aminopropyltriethoxysilane were purchased from «Fluka» (Switzerland), chlorotrimethylsilane, N-hydroxysuccinimide (NHS) and N,Ndicyclohexylcarbodiimide - from «Acros Organics» (Belgium). Other reagents and solvents were obtained from «UkrOrgSyntez» (Ukraine). Amine content in polymers was quantitatively determined by a Bromophenol Blue spectrophotometric assay [16]. 3-Maleimidopropionic acid and its N-hydroxy-succinimidyl ester were synthesized as previously described $[17,18]$.

\section{Cloning and expression of SPA-Cys}

DNA-sequence of SPA-Cys (917 b.p.) encoding the protein starting from Ala37 and ending with Glu339 was obtained via PCR-amplification from chromosomal DNA of S. aureus, isolated with Genomic DNA Purification Kit («Fermentas», Lithuania). A pair of specific primers («Syntol», Russia): sn SPA 5'-ATCATATGGCGCAACACGATGAAGCTCAAC-3' introducing NdeI restriction site and ATG starting codon, and asn SPA-6His-Cys 5'-TACCTCGAGTCAACAGTGGTGGTGGTGGTGGTGTGC GGCCGCTTCCTC-3', introducing 6His-tag for protein purification, C-terminal cysteine residue for sitespecific protein immobilization and $X h o I$ restriction site, were used for PCR amplification.

The spa-cys amplified DNA fragments were ligated with the Esherichia coli expression vector pET24a(+) («Novagen», USA) using NdeI and XhoI sites. The resulting plasmid was used to transform E. coli Rosetta (DE3) host cells («Novagen», USA) for expression.

For expression of SPA-Cys, a modified auto-induction protocol, originally described by Studier [19], was applied as follows: E. coli BL21(DE3) cells harboring the required plasmid were incubated at $37{ }^{\circ} \mathrm{C}$ overnight in $2 \mathrm{ml}$ of $2 \times$ YT medium ( $17 \mathrm{~g}$ peptone from casein, pancreatic digest «Fluka», $10 \mathrm{~g}$ of yeast extract «Helicon», $5 \mathrm{~g} \mathrm{NaCl}$ per $1 \mathrm{~L}$ of water) con- taining $50 \mu \mathrm{g} / \mathrm{ml}$ kanamicin and $1 \%$ glucose. For large-scale production of SPA-Cys protein, 1:1000 dilutions of the overnight culture were used to inoculate $200 \mathrm{ml}$ fresh $2 \times$ YT medium containing $50 \mu \mathrm{g} /$ $\mathrm{ml}$ kanamicin, $25 \mathrm{mM}\left(\mathrm{NH}_{4}\right)_{2} \mathrm{SO}_{4}, 50 \mathrm{mM} \mathrm{KH} \mathrm{PO}_{4}$, $50 \mathrm{mM} \mathrm{Na}_{2} \mathrm{HPO}_{4}, 1 \mathrm{mM} \mathrm{MgSO}_{4}, 0.05 \%$ glucose, $0.2 \%$ $\alpha$-lactose, $0.5 \%$ glycerol. The cultures were allowed to express for $18-24 \mathrm{~h}$ at $37{ }^{\circ} \mathrm{C}$ before the cells were harvested by centrifugation at $3000 \mathrm{~g}$ for $20 \mathrm{~min}$. The bacteria cells were disrupted by sonication on ice with $10 \mathrm{mM}$ Tris-HCl buffer solution ( $\mathrm{pH} 8.0$ ), containing $1 \mathrm{mM}$ EDTA. The cell lysates were precipitated by spinning at $10000 \mathrm{~g}$ for $20 \mathrm{~min}$. The supernatant was used for protein purification. The protein were analyzed by SDS-PAGE in $12 \%$ gel [20]. The aliquots of supernatants and pellets were sampled and mixed with electrophoresis loading buffer containing $7 \%(\mathrm{w} / \mathrm{v}) \mathrm{SDS}, 40 \%(\mathrm{v} / \mathrm{v})$ glycerol, $0.25 \mathrm{M}$ Tris-HCl ( $\mathrm{pH}$ 6.8), $0.0005 \%$ (w/v) bromophenol blue and $100 \mathrm{mM}$ DTT. Gels were stained with Coomassie Brilliant Blue R250. The protein concentrations were measured by densitometry using BSA of known concentration as a standard.

\section{Purification of SPA-Cys}

The purification of SPA-Cys was performed by immobilized-metal affinity chromatography (IMAC) in the native conditions. $1 \mathrm{ml}$ HiTrap chelating column («GE Healthcare», USA) loaded with $\mathrm{Ni}^{2+}$ ions was connected to the FPLC system («Pharmacia», Sweden) and equilibrated with sodium phosphate buffer solution (pH 7.4) containing $300 \mathrm{mM} \mathrm{NaCl}$ and 10 $\mathrm{mM}$ imidazole with flow rate $0.5 \mathrm{ml} / \mathrm{min}$. The soluble protein fractions from lysates of the induced Rosetta (DE3) cells carrying the plasmid pET24-SPA-6HisCys were filtered through $0.45 \mu \mathrm{m}$-membrane PVDF filter («Millipore», USA) and were applied to the column. The column was washed with the mentioned buffer to remove non-specifically bound proteins, and SPA-Cys was eluted with sodium phosphate buffer solution (pH 7.4) containing $300 \mathrm{mM} \mathrm{NaCl}$ and 300 $\mathrm{mM}$ imidazole. The homogeneity of the purified protein was analyzed by SDS-PAGE in $12 \%$ gel [20]. SPA-Cys concentration was determined using the value of $\mathrm{A}_{280}$ adsorption, calculated from the amino acid 


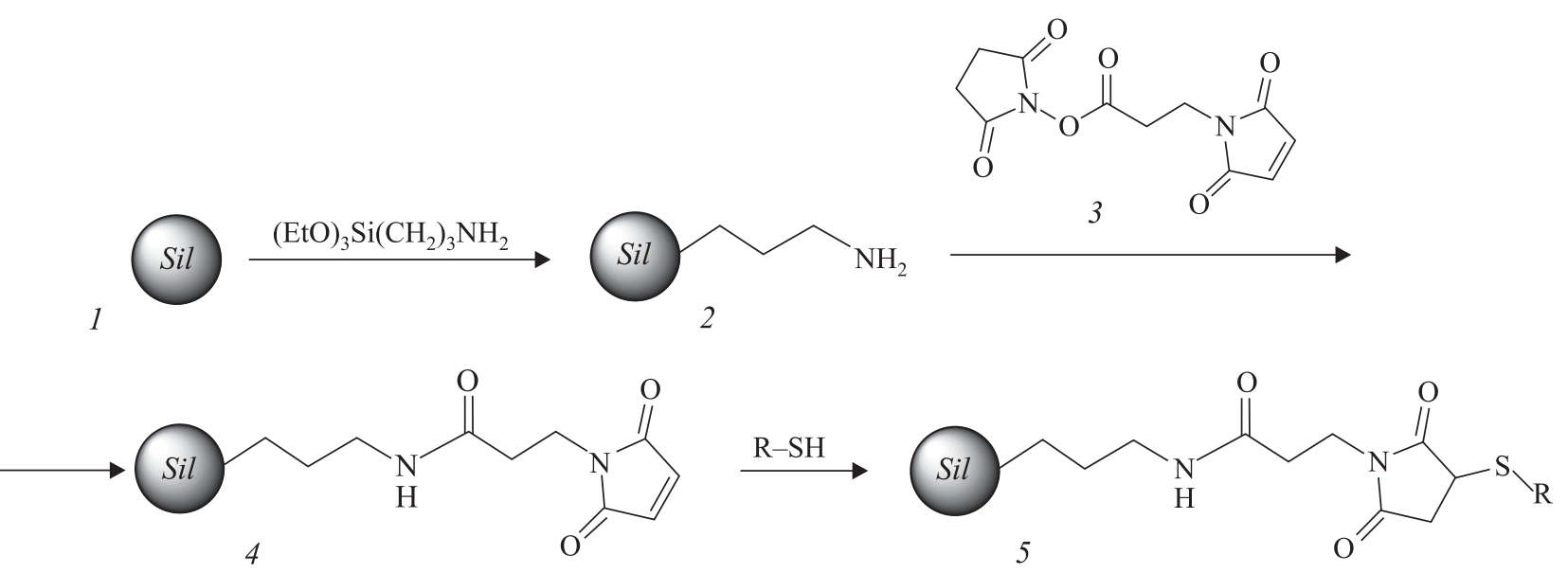

Fig. 1. Schematic representation of the synthesis of maleimide-modified matrix and its reaction with thiols. Sil - silica beads

sequence with Vector NTI software. For large-scale purification procedure, a 26/20 XK column («GE Healthcare», USA) packed with $20 \mathrm{ml}$ of Ni-NTA Superflow resin («Qiagen», Germany) was used.

\section{Preparation of the maleimide-functionalized silica beads}

Aminopropyl-modified matrix 2 (Fig. 1) was obtained by the reaction of spherical silica beads 1 with 3-aminopropyltriethoxysilane in $95 \%$ ethanol and subsequent surface treatment with chlorotrimethylsilane in pyridine to block polar silanol groups, following the general procedure described for glass beads amination [21]. $1.0 \mathrm{~g}$ of aminopropyl-silica was treated with $10 \mathrm{ml}$ solution of reagent $\mathbf{3}$, hydroxysuccinimide ester of 3-maleimidopropionic acid, (1.2 mmol) in dry DMF for $24 \mathrm{~h}$ at ambient temperature with occasional stirring. The polymer was filtered off, washed with DMF $(3 \times 3 \mathrm{ml})$, and remaining free $\mathrm{NH}_{2}$ groups were blocked with $10 \%$ acetic anhydride in pyridine ( $5 \mathrm{ml}, 10 \mathrm{~min})$. The maleimide-functionalized silica beads 4 were collected by filtration, extensively washed with pyridine, chloroform, methanol and diethyl ether, and dried in vacuum.

\section{Immobilization}

of SPA-Cys on maleimide-functionalized silica beads

Immobilization of SPA-Cys on maleimide-functionalized silica was performed by the method described by Mallik et al. [22]. Before immobilization, the maleimide-functionalized silica beads were washed five times with $1.3 \mathrm{M}$ potassium phosphate buffer solution, $\mathrm{pH}$ 7.0. Then $5 \mathrm{~mL}$ solution of SPA-Cys in 1.3 $\mathrm{M}$ potassium phosphate buffer solution, $\mathrm{pH} 7.0$ with concentration $2 \mathrm{mg} / \mathrm{mL}$ was added to $0.5 \mathrm{~g}$ of the maleimide-functionalized silica beads. This mixture was degassed and the reaction was carried out at $4{ }^{\circ} \mathrm{C}$ for $36 \mathrm{~h}$ with shaking. The obtained affinity chromatography stationary phase was separated from the reaction mixture by centrifugation and was washed five times with $1.3 \mathrm{M}$ potassium phosphate buffer solution ( $\mathrm{pH}$ 7.0). After washing we estimated that about 2.1-2.3 mg of SPA-Cys was attached to 1 $\mathrm{g}$ of silica. The remaining free reactive groups were blocked with $10 \mathrm{mM}$ cysteine.

\section{IgG purification on SPA-Cys affinity column}

Before application, the affinity chromatography stationary phase was washed with at least 100 column volumes of $70 \mathrm{mM}$ potassium phosphate buffer solution ( $\mathrm{pH}$ 7.4). Blood serum of immunized mice, diluted with the same buffer solution was loaded onto the chromatographic column, containing $1 \mathrm{ml}$ of the equilibrated SPA-Cys-based affinity chromatography stationary phase with the flow rate $0.5 \mathrm{ml} / \mathrm{min}$. The column was washed with the same buffer solution to remove unbound material, and bound antibodies were eluted with $0.1 \mathrm{M} \mathrm{Na-citrate}$ buffer so- 
lution ( $\mathrm{pH}$ 3.8). A purity of the eluted antibodies was checked by $12 \%$ SDS-PAGE.

\section{SPR spectrometric analysis of protein-protein interactions}

SPR analysis was performed using a measuring flowcell of the spectrometer «Plasmon-4M» and the peristaltic pump «Ismatec» (the pump speed of $\sim 40 \mu \mathrm{l} /$ min). At first the measuring flow-cell was thoroughly washed by working buffer solution (PBS) to stabilize the SPR signal. Then a sample (usually $120 \mu \mathrm{l}$ ) was injected and incubated with the pump switched off for $30 \mathrm{~min}$ for protein immobilization on the sensor surface and for $10 \mathrm{~min}$ for interactions of immobilized components with their molecules-partners. After that the measuring flow-cell was washed by PBS again until a stable SPR signal is obtained. To distinguish an actual sensor response caused by the interactions between the sample and sensor surface or preliminary immobilized components, from the signal caused by random fluctuations of the medium refractive index, it was necessary prior to measuring the SPR response to wash the flow-cell before and after each sample by the same buffer solution [8].

\section{Results and Discussion}

To design the ORF of recombinant protein SPA-Cys, four features were taken into consideration: 1) the signaling peptide and a $C$-terminal anchoring part of the natural SPA do not interact with immunoglobulins (moreover, the $C$-terminal hydrophobic part could cause some complications in the expression of the recombinant protein); 2) the IgG-binding region consists of five highly homologous domains (E, D, $\mathrm{A}, \mathrm{B}$ and $\mathrm{C})$; 3 ) the presence of 6His-tag in the protein assures its efficient purification by immobilizedmetal affinity chromatography; 4) there is no cysteine residue in the IgG-binding domains, and the addition of cysteine residue to the C-terminus of the recombinant protein allows its reliable immobilization on the gold sensor surface and on the maleimide-functionalized silica surface. Therefore, we excluded the sequences not required for IgG-binding (signaling and a $C$-terminal anchoring parts of SPA) and the designed ORF of recombinant protein SPA-Cys con-

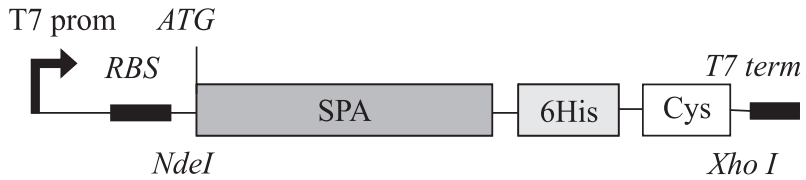

Fig. 2. Schematic representation of SPA-6His-Cys expression cassette in $p E T-24 a(+)$ plasmid vector

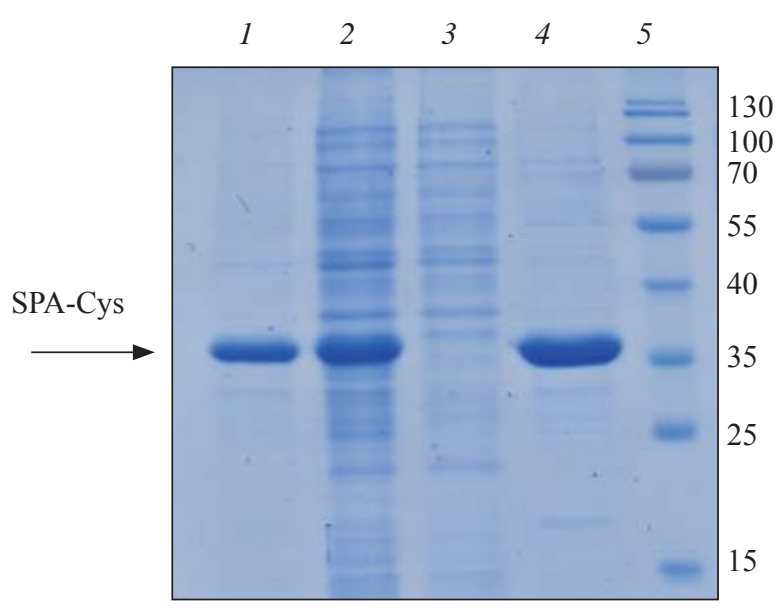

Fig. 3. Electrophoregram of expression and purification of SPACys. 1, 4 - Ni-NTA purified SPA-Cys; 2 - soluble protein fractions from induced Rosetta (DE3) cells carrying plasmid pET-24SPA-6His-Cys; 3 - proteins washed from the column with sodium phosphate buffer, $\mathrm{pH} 7.4 ; 5$ - molecular weight markers (from top to bottom: $130,100,70,55,40,35,25,15 \mathrm{kDa})$. Amount of protein corresponding to $5-15 \mu 1$ of induced $E$. coli culture was loaded on each lane of $12 \%$ SDS-PAGE. The arrow marks the position of SPA-Cys protein

tained the sequences encoding all five IgG-binding domains, 6His-tag and C-terminal cysteine (Fig. 2). The auto-induction expression method, in contrast to the more expensive IPTG induction method, does not require large volumes of culture medium and special equipment. Adtionally, prolonged cultivation time (up to 24 hours) allows obtaining high yields of recombinant protein [19]. The applied cultivation conditions provided a high-level expression of target proteins ( $\sim 1 \mathrm{~g} / 1$ E. coli culture). We have shown that SPA-Cys (MW $=34.5 \mathrm{kDa})$ accumulated in bacteria is in the soluble form. SPA-Cys was obtained at the multi-milligram scale in a functionally active state with purity $\sim 95 \%$ by one-step IMAC (Fig. 3). The IgG-binding activity of recombinant protein was confirmed by ELISA with rabbit IgG, and the pres- 
ence of the C-terminal cysteine residue - with the Ellman's reagent.

The C-terminal cysteine residue provided the oriented immobilization of SPA on maleimide-activated matrix allowing the IgG-binding sites of SPA to be exposed for the interactions with IgG. The synthesis

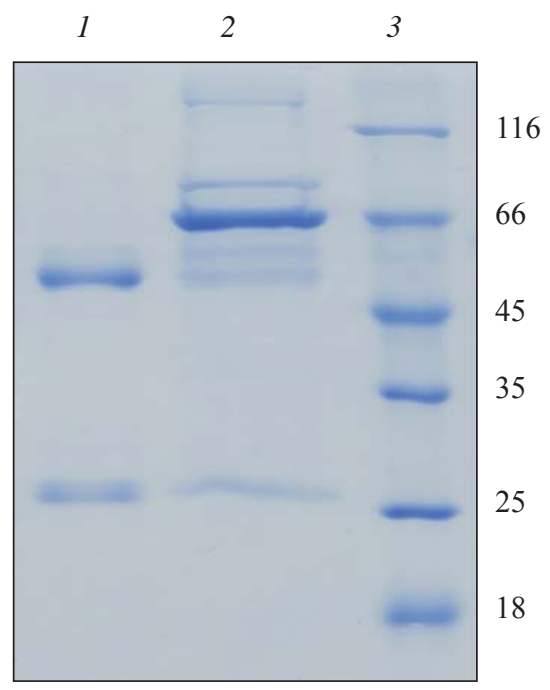

Fig. 4. Purification of IgG on SPA-Cys-based affinity chromatography stationary phase. 1 - purified IgG; 2 - proteins of the blood serum which were loaded on the column; 3 - molecular weight markers (from top to bottom: $116,66,45,35,25,18 \mathrm{kDa}$ )

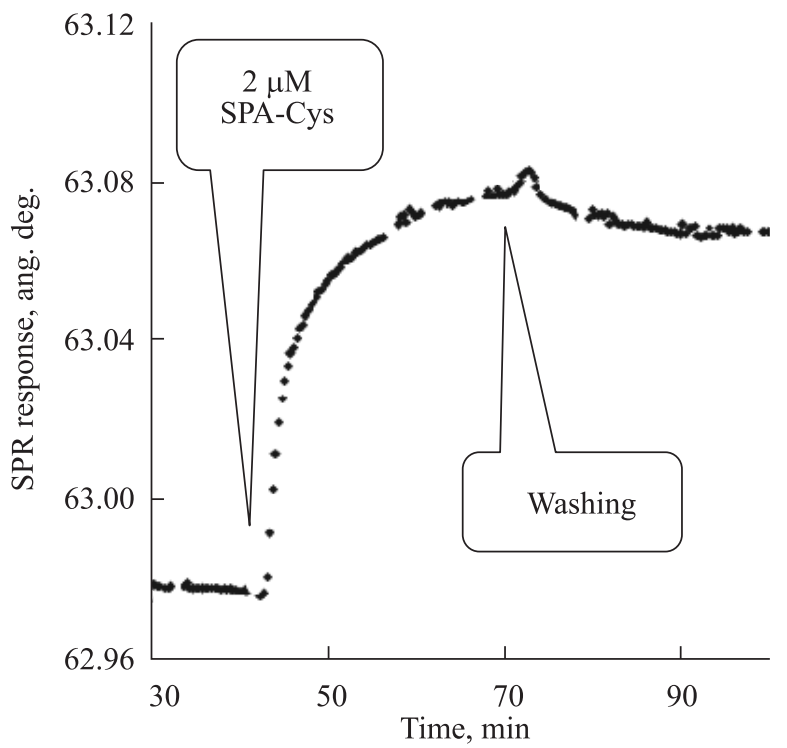

of functionalized silica beads is shown schematically in Fig. 1. The heterobifunctional cross-linking reagent 3 was used for the surface modification. This reagent contains two functional groups of different reactivity, namely, maleimide residue able to interact selectively with thiols, and hydroxysuccinimide ester reacting with amines to form an amide bond. Thus reagent 3 allows the introduction of thiol-specific maleimide groups into the amine-modified polymer.

The matrix amination was performed using the reaction of spherical silica beads 1 with 3-aminopropyltriethoxysilane [21]. The amine content in various samples of aminopropyl-functionalized silica beads 2 was in the range $100-150 \mu \mathrm{mol} / \mathrm{g}$. The treatment of this polymer with the amine-reactive reagent 3 in DMF resulted in the formation of modified matrix 4 containing a thiol-specific function on a relatively flexible linker. The concentration of maleimide groups in the polymer sample was found to be ca. 70-90 $\mu \mathrm{mol} / \mathrm{g}$ (which corresponds to the difference of amine content before and after the reaction with 3), coupling yields up to $75 \%$. The reaction of maleimide-modified silica with thiols, including the proteins containing free SH groups, leads to their covalent attachment to the solid matrix (product 5, Fig. 1).

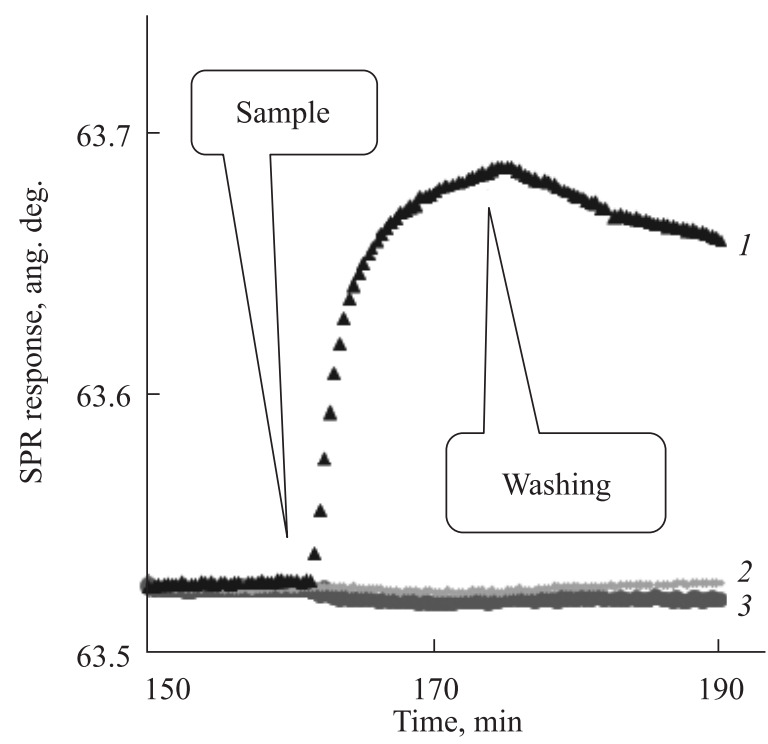

Fig. 5. SPR sensogram representing the immobilization of $2 \mu \mathrm{M}$ SPA-Sys on a gold sensor surface of SPR spectrometer «Plasmon-4m»

Fig. 6. SPR sensograms representing the interactions of the bioselective element based on SPA-Cys immobilized on a gold sensor surface with the solutions (all $40 \mu \mathrm{g} / \mathrm{ml}$ ) of IgG (1), Glucose Oxidase (2) and BSA (3) 
The immobilization of SPA-Cys on the maleimide-functionalized matrix was performed under mild conditions. The obtained affinity chromatography stationary phase was used for one-step purification of antibodies. According to the SDS-PAGE results, the purity of $\mathrm{IgG}$ in eluted fractions was over $95 \%$ (Fig. 4). IgG-binding capacity of the SPA-Cys affinity chromatography stationary phase was around $10-12 \mathrm{mg} / \mathrm{ml}$ and it was stable in the $\mathrm{pH}$ range from 2.0 to 11.0 and in the presence of 0.1 $\%$ detergent (TWEEN 20, TWEEN 80 or Triton X-100), 8 M Urea, 6 M Guanidine hydrochloride, $70 \%$ ethanol. Thus, the combination of efficient expression systems and an optimal method for SPA immobilization on silica beads resulted in a high capacity of the affinity chromatography stationary phase for the IgG purification.

For the SPA-Cys immobilization on a gold sensor surface of SPR spectrometer «Plasmon-4m», a sample of the purified recombinant Staphylococcal protein A was injected into the measuring flow-cell and incubated there. It led to a significant increase in the sensor signal (Fig. 5). Further prolonged wash of the flow-cell by PBS caused only a slight decrease in the sensor signal. It means that only a small part of the sensor signal was caused by weakly bound molecules, and the major part of SPA-Cys molecules was firmly immobilized on the gold sensor surface.

To check, whether the immobilized molecules of SPA-Cys retain their immunoglobulin-binding properties, human IgG was injected into the measuring flow-cell. The sensogram (Fig. 6) shows that the introduction of $40 \mu \mathrm{g} / \mathrm{ml} \mathrm{IgG}$ causes a significant sensor response without a noteworthy decrease during prolonged PBS wash. Obviously, the SPA-Cys molecules immobilized on the gold sensor surface demonstrated a high immunoglobulin-binding activity.

At the same time, the injection of other proteins (BSA and Glucose Oxidase, $40 \mu \mathrm{g} / \mathrm{ml}$ ) does not cause noticeable changes in the sensor response (Fig. 6). So, the created bioselective element of the SPR immunosensor based on the recombinant protein SPA-Cys demonstrated the high selectivity of sensor response. Further characterizations of this bioselective element are in progress.

\section{Conclusions}

The purified recombinant Staphylococcal protein A with cysteine residue was successfully used for the preparation of the affinity chromatography stationary phase and the formation of bioselective elements of immunosensor. The affinity chromatography stationary phase based on SPA-Cys efficiently purified the antibodies in functionally active form from serum in one-step procedure. The bioselective element of the surface plasmon resonance immunosensor based on SPA-Cys showed high activity and selectivity.

\section{Acknowledgements}

The authors thank Dr. Pavlova M., Dr. Gilchuk P., Mrs. Tsapenko M. and Mr. Flyak A. for their helpful discussions and valuable assistance in this research. The authors express their sincere gratitude to $\mathrm{Mr}$. Avants J. for his kind linguistic help.

\section{Funding}

This work was partially supported by STCU project N 6044; 2015.

\section{REFERENCES}

1. Sidorin EV, Solov'eva TF. IgG-binding proteins of bacteria. Biochemistry (Mosc). 2011;76(3):295-308.

2. Forsgren A, Sjöquist J. «Protein A» from S. aureus. I. Pseudo-immune reaction with human gamma-globulin. J Immunol. 1966;97(6):822-7.

3. Abrahmsén L, Moks T, Nilsson B, Hellman U, Uhlén M. Analysis of signals for secretion in the staphylococcal protein A gene. EMBO J. 1985;4(13B):3901-6.

4. Moks T, Abrahmsén L, Nilsson B, Hellman U, Sjöquist J, Uhlén $M$. Staphylococcal protein A consists of five IgG-binding domains. Eur J Biochem. 1986;156(3):637-43.

5. Sjodahl J. Repetitive sequences in protein A from Staphylococcus aureus. Arrangement of five regions within the protein, four being highly homologous and Fc-binding. Eur J Biochem. 1977;73(2):343-51.

6. Hober S, Nord K, Linhult M. Protein A chromatography for antibody purification. J Chromatogr B Analyt Technol Biomed Life Sci. 2007;848(1):40-7.

7. Makaraviciute A, Ramanaviciene A. Site-directed antibody immobilization techniques for immunosensors. Biosens Bioelectron. 2013;50:460-71.

8. Rachkov A, Holodova Y, Ushenin Y, Miroshnichenko D, Telegeev $G$, Soldatkin A. Development of bioselective element of SPR spectrometer for monitoring of oligonucleotide interactions and comparison with thermodynamic calculations. Sens Lett. 2009;7(5):957-61. 
9. Kanno S, Yanagida Y, Haruyama T, Kobatake E, Aizawa M. Assembling of engineered IgG-binding protein on gold surface for highly oriented antibody immobilization. J Biotechnol. 2000;76(2-3):207-14.

10. Dubois L, Nuzzo R. Synthesis, structure, and properties of model organic surfaces. Annu Rev Phys Chem. 1992; 43(1): 437-63.

11. Wong LS, Khan F, Micklefield J. Selective covalent protein immobilization: strategies and applications. Chem Rev. 2009;109(9):4025-53.

12. Hermanson GT. Bioconjugate techniques. 2nd Ed. Amsterdam: «Academic Press», 2008; 1202 p.

13. Venkatesan $N$, Kim BH. Peptide conjugates of oligonucleotides: synthesis and applications. Chem Rev. 2006;106(9): 3712-61.

14. Lu K, Duan QP, Ma L, Zhao DX. Chemical strategies for the synthesis of peptide-oligonucleotide conjugates. Bioconjug Chem. 2010;21(2):187-202.

15. Peng H, Chen W, Cheng Y, Hakuna L, Strongin R, Wang B. Thiol reactive probes and chemosensors. Sensors (Basel). 2012;12(11):15907-46.

16. Krchnák V, Vágner J, Safar P, Lebl M. Noninvasive continuous monitoring of solid-phase peptide synthesis by acid-base indicator. Collect Czech Chem Commun. 1988; 53(11): 2542-48.

17. Keller $O$, Rudinger $J$. Preparation and some properties of maleimido acids and maleoyl derivatives of peptides. Helv Chim Acta. 1975;58(2):531-41.

18. Song HY, Ngai MH, Song ZY, MacAry PA, Hobley J, Lear $M J$. Practical synthesis of maleimides and coumarin-linked probes for protein and antibody labelling via reduction of native disulfides. Org Biomol Chem. 2009;7(17):3400-6.

19. Studier FW. Protein production by auto-induction in high density shaking cultures. Protein Expr Purif. 2005;41(1):207-34.

20 . Westermeir $R$. Electrophoresis in practice: a guide to methods and application of DNA and protein separations. Weinheim: «VCH», 1997. 331 p.

21. Oligonucleotide synthesis: a practical approach. Ed. Gait MJ. Oxford: «IRL Press», 1984. 217 p.

22. Mallik R, Wa C, Hage DS. Development of sulfhydryl-reactive silica for protein immobilization in high-performance affinity chromatography. Anal Chem. 2007;79(4):1411-24.

\section{Рекомбінантний білок A Staphylococcus aureus із залишком цистеїну для приготування стаціонарної фази афінної хроматографії та для розробки імуносенсорів}

О. Б. Горбатюк, А. О. Бахмачук, Л. В. Дубей,

М. О. Усенко, Д. М. Іродов, О. В. Окунєв, О. М. Костенко, О. Е. Рачков, В. А. Кордюм

Мета. Отримання рекомбінантного білка A S. aureus iз залишком цистеїну (SPA-Cys) та його застосування для афінної хроматографії та формування біоселективного елемента імуносенсора. Методи. Генно-інженерними методами конструювали та експресували в E.coli послідовність ДНК, яка кодує п'ять IgG-зв'язувальних доменів SPA, His-таг і цистеїн. Отриманий рекомбінантний білок SPA-Cys іммобілізували на малеїмід-активованих мікрогранулах силікагелю для приготування біоафінного сорбенту та на золотій сенсорній поверхні для розробки імуносенсора. Результати. Синтезом у E. coli був отриманий білок SPA-Cуs в розчинній формі з високим виходом. Очищений рекомбінантний білок А має високу IgG-зв'язувальну активність. Смність біоафінного сорбенту 3 іммобілізованим SPA-Суs складала 10-12 мг IgG/мл. Одностадійна процедура афінної хроматографії сироватки крові дозволяє отримувати IgG з чистотою більш ніж 95 \%. Показано, що біоселективний елемент імуносенсора, сформований на основі SPA-Суs, вибірково взаємодіє з IgG людини і не взаємодіє 3 контрольними білками. Висновки. Рекомбінантний білок SPA-Суs був успішно використаний для приготування стаціонарної фази афінної хроматографії і формування біоселективного елемента імуносенсора.

Ключов і слов а: антитіла, рекомбінантний білок А $S$. aureus, іммобілізація білка, афінна хроматографія, імуносенсор, поверхневий плазмонний резонанс.

Рекомбинантный белок A $S$. aureus с остатком цистеина для приготовления стационарной фазы аффинной хроматографии и для разработки иммуносенсоров

О. Б. Горбатюк, А. О. Бахмачук, Л. В. Дубей, М. А. Усенко, Д. М. Иродов, О. В. Окунев, А. Н. Костенко, А. Э. Рачков, В. А. Кордюм

Цель. Получение рекомбинантного белка A S. aureus с остатком цистеина (SPA-Cys) и его применение для аффинной хроматографии и формирования биоселективного элемента иммуносенсора. Методы. Генно-инженерными методами конструировали и экспрессировали в E.coli последовательность ДНК, которая кодирует пять IgG-связывающих доменов SPA, His-таг и цистеин. Полученный рекомбинантный белок SPACys иммобилизовали на малеимид-активированных микрогранулах силикагеля для приготовления биоафинного сорбента и на золотой сенсорной поверхности для разработки иммуносенсора. Результаты. Синтезом в E. coli был получен белок SPA-Суs в растворимой форме с высоким выходом. Очищенный рекомбинантный белок А имеет высокую IgGсвязывающую активность. Емкость синтезированного с использованием SPA-Суs биоафинного сорбента составляла 10-12 мг IgG/мл. Одностадийная процедура аффинной хроматографии сыворотки крови позволяет получать IgG с чистотой более $95 \%$. Показано, что биоселективный элемент иммуносенсора, сформированный на основе SPA-Cуя, избирательно взаимодействует c IgG человека и не взаимодействует с контрольными белками. Выводы. Рекомбинантный белок SPA-Cys был успешно использован для приготовления стационарной фазы аффинной хроматографии и формирования биоселективного элемента иммуносенсора.

Кл ючев ы е сл ов а: антитела, рекомбинантный белок А $S$. aureus, иммобилизация белка, аффинная хроматография, иммуносенсор, поверхностный плазмонный резонанс.

Received 10.01.2015 